\title{
Development of a Land Use Carbon Inventory for Agricultural Soils in the Canadian Province of Ontario
}

\author{
Ahmed Laamrani ${ }^{1,2,3, * \mathbb{D}}$, Paul R. Voroney ${ }^{2}$, Adam W. Gillespie ${ }^{2}$ and Abdelghani Chehbouni ${ }^{1,4}$ \\ 1 Center for Remote Sensing Applications (CRSA), Mohammed VI University (UM6P), \\ Ben Guerir 43150, Morocco; abdelghani.chehbouni@um6p.ma \\ 2 School of Environmental Sciences, University of Guelph, Guelph, ON N1G 2W1, Canada; \\ pvoroney@uoguelph.ca (P.R.V.); agilles@uoguelph.ca (A.W.G.) \\ 3 Department of Geography, Environment \& Geomatics, University of Guelph, Guelph, ON N1G 2W1, Canada \\ 4 Centre d'Études Spatiales de la Biosphère/Institut de Recherche pour le Développement (CESBIO/IRD), \\ CNES/CNRS/INRAE/UPS/Université de Toulouse, CEDEX 9, 31401 Toulouse, France \\ * Correspondence: ahmed.laamrani@um6p.ma; Tel.: +212-662099650
}

Citation: Laamrani, A.; Voroney, P.R.; Gillespie, A.W.; Chehbouni, A.

Development of a Land Use Carbon Inventory for Agricultural Soils in the Canadian Province of Ontario. Land 2021, 10, 765. https://doi.org/ 10.3390/land10070765

Academic Editors: Ritvik Sahajpal and Alyssa Whitcraft

Received: 11 June 2021

Accepted: 15 July 2021

Published: 20 July 2021

Publisher's Note: MDPI stays neutral with regard to jurisdictional claims in published maps and institutional affiliations.

Copyright: (c) 2021 by the authors. Licensee MDPI, Basel, Switzerland. This article is an open access article distributed under the terms and conditions of the Creative Commons Attribution (CC BY) license (https:/ / creativecommons.org/licenses/by/ $4.0 /)$.

\begin{abstract}
Globally, agricultural soils are being evaluated for their role in climate change regulation as a potential sink for atmospheric carbon dioxide $\left(\mathrm{CO}_{2}\right)$ through sequestration of organic carbon as soil organic matter. Scientists and policy analysts increasingly seek to develop programs and policies which recognize the importance of mitigation of climate change and insurance of ecological sustainability when managing agricultural soils. In response, many countries are exploring options to develop local land-use carbon inventories to better understand the flow of carbon in agriculture to estimate its contribution to greenhouse gas (GHG) reporting. For instance, the Canadian province of Ontario does not currently have its own GHG inventory and relies on the Canada's National Inventory Report (NIR). To address this, the province explored options to develop its own land-use carbon inventory to better understand the carbon resource in agricultural soils. As part of this undertaking, a gap analysis was conducted to identify the critical information gaps and limitations in estimating soil organic carbon (SOC) monitoring to develop a land-use carbon inventory (LUCI) for the cropland sector in Ontario. We conducted a review of analytical and modeling methods used to quantify GHG emissions and reporting for the cropland sectors in Canada, and compared them with the methods used in seven other countries (i.e., France, United Kingdom; Germany; United States of America, Australia, New Zealand, and Japan). From this comparison, four target areas of research were identified to consider in the development of a cropland sector LUCI in Ontario. First, there needs to be a refinement of the modelling approach used for SOC accounting. The Century model, which is used for Ontario's cropland sector, can benefit from updates to the crop growth model and from the inclusion of manure management and other amendments. Secondly, a raster-based spatially explicit modelling approach is recommended as an alternative to using polygon-based inputs for soil data and census information for land management. This approach can leverage readily available Earth Observation (EO) data (e.g., remote sensing maps, digital soil maps). Thirdly, the contributions from soil erosion need to be included in inventory estimates of SOC emissions and removals from cropland. Fourth, establishment of an extensive network of long-term experimental sites to calibrate and validate the SOC models (i.e., CENTURY) is required. This can be done by putting in place a ground-truth program, through farmer-led research initiatives and collaboration, to deal with uncertainties due to spatial variability and regional climates. This approach would provide opportunities for farmers to collaborate on data collection by keeping detailed records of their cropping and soil management practices, and crop yields.
\end{abstract}

Keywords: agricultural soils; soil organic carbon; crop land-use carbon inventory; CENTURY model; greenhouse gas (GHG) 


\section{Introduction}

About $50 \%$ of the world's habitable land is used for agriculture [1] and cultivated soils encompass about $12 \%$ of the global total soil organic carbon (SOC) stock [2]. Soils can be both a net source or sink for the three principal greenhouse gases (GHGs), carbon dioxide $\left(\mathrm{CO}_{2}\right)$, nitrous oxide $\left(\mathrm{N}_{2} \mathrm{O}\right)$, and methane $\left(\mathrm{CH}_{4}\right)$. Indeed, SOC changes in cultivated soils are regulated by complex interactions between the local soil environmental and climatic conditions, as well as the agricultural management practices [3]. Many studies have suggested that changes in SOC can impact atmospheric $\mathrm{CO}_{2}$ concentrations [4]. For instance, it is well known that historical agricultural activities have resulted in a substantial decline in SOC stocks; and that soil and cropping practices are a potentially powerful tool for climate change mitigation through $C$ sequestration [5-10]. Numerous international initiatives (i.e., 4p1000, 2015) have recognized agricultural soils as an important contributor in the mitigation of climate change suggesting that adaptability of agricultural land-use practices can play a crucial role where food security and climate change are concerned [11]. Therefore, the development of a local land use carbon inventory (LUCI) is the first step to better understand the importance of SOC in agricultural cropland and soil conservation.

Canadian agricultural soils are important for climate regulation by being either a source of GHG emissions, or by sequestering organic carbon and nitrogen as a sink in stable SOC [12]. Since agricultural soils accounted for about $8 \%$ of Canada's total GHGs emissions in 2015, the Canadian government is now considering strategies for SOC sequestration to reduce GHG emissions. In addition, Canada's policies on climate change now acknowledge the importance of soils, and require proper, comparable and reliable information to report on carbon stocks and GHGs emissions from soil [13]. The importance of the agricultural land use sector and its contribution to GHG reduction has been reinforced by the 2015 Paris Agreement of the United Nations Framework Convention on Climate Change (UNFCCC). Thus, there is a growing interest in estimating the net GHG balance in response to land-use changes involving agriculture for national-scale reporting.

Reports on SOC stocks and GHGs emissions from agricultural soils is of special importance to the province of Ontario because it contains significant high-intensity farmland in Canada, with a total number of 49,600 farms according to the 2016 Census of Agriculture [14]. Nevertheless, Ontario does not currently include emissions and removals of GHGs from the agricultural land use sector in its GHG inventory or GHG reduction targets. Therefore, to guide the development of a carbon policy, there is a need to develop a LUCI for the province. This carbon inventory could (i) provide a better understanding of the potential role of terrestrial carbon in achieving Ontario's objectives in climate change mitigation; (ii) provide an opportunity for the province to improve data sources and reduce data gaps by aligning scientific efforts with federal government departments; (iii) develop more comprehensive estimates of carbon stored and released by landscapes; and (iv) increase understanding of the mechanisms of how agricultural lands and soils emit and store carbon. In this context, this study aimed to contribute to a better understanding of the current status of land use SOC inventories for the cropland sector in Ontario and to identify the critical information gaps and limitations in estimating agriculture management effects on SOC monitoring.

The objectives of this report are to (i) conduct a review of scientific literature on cropland land-use and Intergovernmental Panel on Climate Change (IPCC) best practice guidance; (ii) review and describe practices employed to estimate SOC stocks and GHG fluxes for Ontario, Canada's NIR and for other national-level and sub-national jurisdictions; (iii) compare practices used in Canada's NIR and Ontario to best practices and other jurisdictions; and (iv) identify gaps and limitations in the Canada's inventory and propose possible improvements for future LUCI for the cropland sector in Ontario.

\section{Jurisdictional Scan}

In this synthesis review, we reviewed 57 publications specifically designed to answer the study objectives. These publications encompass reports (i.e., The IPCC publications); 
scientific papers; NIRs from Canada and seven other countries; selected states in the US (i.e., California and Michigan); and from provinces across Canada. It is important to note that this study focused only on methodologies for estimating and reporting GHGs from the cropland sector.

\subsection{Synthesis of Reporting of GHG Emissions Reporting Methods from Agricultural Soils Scan}

The Intergovernmental Panel for Climate Change (IPCC 2014; [15]) states that arable and tillable land, and agroforestry systems are to be included in cropland. These lands encompass all perennial and annual crops, as well as temporary fallow land (i.e., land left for one or more years without cultivation or cropping). Perennial crops include trees and shrubs, orchards, vineyards and plantations such as Christmas trees. Annual crops include cereals, oilseeds, forages, vegetables, and root crops. Land normally used for cultivation of annual crops, but temporarily used for forage crops or grazing as part of an annual crop-pasture rotation (mixed system), also is included under cropland. The amount of organic $\mathrm{C}$ retained in or removed from cropland depends on crop type, management practices, and soil and climate variables. When considering above-ground $C$ stocks, crops such cereals that are harvested each year are not included in inventories because there is no long-term storage of $C$ as biomass, whereas biomass $C$ in perennial woody vegetation such as vineyards is included. In cropland, the major component of long-term carbon stocks is found in soils, and changes in stocks can occur from management practices such as crop type and rotation, tillage, drainage, residue management and application of organic amendments. Therefore, knowledge of management information is often used to predict whether the amount of $C$ stored in a cropland soil is increasing or decreasing. For example, if there has been no change in management practices over several years, the SOC stocks are reasonably assumed to be at steady state, hence the change in $C$ stocks can be deemed to be zero (with the assumption that there is no soil erosion).

This study reviewed the methodology for estimating and reporting GHG emissions from cropland remaining cropland in the IPCC 2006 [16]. These methodologies were first produced in the IPCC 1996 [17] under the guidelines for land use, land-use change, and forestry (LULUCF). In 2003, the IPCC [18] released the Good Practice Guidance, where Section 3 related to LULUCF, and these practices were updated in 2006 [19]. This 2006 methodology was the effort of a large international scientific voluntary collaboration, and represents the current Good Practices version in use. Most nations follow the 2006 guidelines as a mandatory requirement. The IPCC methodology is based on a three-tiered levels approach (i.e., T1, T2, T3) depending on the scale and the quality of the data available. This tiered approach is summarized in Table 1.

Table 1. Summary of the IPCC three-tiered approach for calculating soil C stock changes. Data were compiled from the 2006 IPCC report [16].

\begin{tabular}{|c|c|c|c|}
\hline & Tier 1 & Tier 2 & Tier 3 \\
\hline $\begin{array}{c}\text { Scale and } \\
\text { Required } \\
\text { Data }\end{array}$ & $\begin{array}{l}\text { Corresponds to the } \\
\text { default method with } \\
\text { emission or stock change } \\
\text { factors listed in the } \\
\text { guidelines. It } \\
\text { corresponds to very } \\
\text { large-scale approaches, } \\
\text { with average emission } \\
\text { factors for large } \\
\text { eco-regions of the world } \\
\text { (e.g., boreal, tropical, } \\
\text { temperate). }\end{array}$ & $\begin{array}{l}\text { Uses the same calculation } \\
\text { methods but makes use } \\
\text { of national or } \\
\text { country-representative } \\
\text { data in the derivation of } \\
\text { emissions and stock } \\
\text { change factors. It uses } \\
\text { specific data linked to a } \\
\text { state, region, landscape, } \\
\text { or even project. Requires } \\
\text { more accurate emission } \\
\text { factors usually obtained } \\
\text { by intensive field } \\
\text { measurements at the } \\
\text { required scale. }\end{array}$ & $\begin{array}{l}\text { Much more detailed } \\
\text { approach that uses } \\
\text { dynamic modeling } \\
\text { and/or based on } \\
\text { extensive } \\
\text { measurements to } \\
\text { predict SOC stock } \\
\text { changes. Usually, it } \\
\text { includes biophysical } \\
\text { modeling and requiring } \\
\text { data on land use and } \\
\text { management. }\end{array}$ \\
\hline
\end{tabular}


Table 1. Cont.

\begin{tabular}{|c|c|c|c|}
\hline & Tier 1 & Tier 2 & Tier 3 \\
\hline $\begin{array}{l}\text { Carbon } \\
\text { stocks in } \\
\text { soil }\end{array}$ & $\begin{array}{l}\text { For changes in soil C } \\
\text { from both organic and } \\
\text { mineral soils uses default } \\
\text { coefficients and stratifies } \\
\text { the land areas by climatic } \\
\text { region. For emissions } \\
\text { from liming, uses default } \\
\text { emission factors as given } \\
\text { in IPCC guidelines. }\end{array}$ & $\begin{array}{l}\text { Based on direct } \\
\text { measurements of soil C } \\
\text { stocks. Mutually organic } \\
\text { and mineral soils use } \\
\text { mixture of default } \\
\text { and/or country-specific } \\
\text { coefficients and area } \\
\text { estimates of increasingly } \\
\text { high spatial resolution. }\end{array}$ & $\begin{array}{l}\text { Country-specific } \\
\text { approach at fine spatial } \\
\text { scale (e.g., modeling, } \\
\text { measurements) }\end{array}$ \\
\hline
\end{tabular}

The IPCC treats mineral soils and organic soils differently. To estimate GHGs emissions and soil $\mathrm{C}$ stock changes for mineral soils, the IPCC developed a series of mathematical equations that relate data on land use management activities to emission factors to estimate fluxes from these activities. In organic soils, carbon stocks are estimated by three-tiered approach approaches summarized in Table 2.

$$
\Delta \mathrm{C}_{\text {Mineral }}=\mathrm{SOC}_{0}-\mathrm{SOC}_{(0-\mathrm{T})} / \mathrm{D}
$$

Table 2. Description of the methods used to estimate carbon stocks from both organic and mineral soils according to equations in the 2006 IPCC guidance [16].

\begin{tabular}{|c|c|c|}
\hline $\begin{array}{l}\text { Estimation } \\
\text { Method }\end{array}$ & $\begin{array}{l}\text { Mineral } \\
\text { Soils }\end{array}$ & $\begin{array}{c}\text { Organic } \\
\text { Soils }\end{array}$ \\
\hline Tier 1 & $\begin{array}{l}\text { Equation (1) is usually applied to } \\
\text { estimate change in SOC stocks in } \\
\text { mineral soils by subtracting the } \\
\text { carbon stock in the last year of an } \\
\text { inventory time period }\left(\mathrm{SOC}_{0}\right) \text { from } \\
\text { the carbon stock at the start of the } \\
\text { inventory time period (SOC }(0-\mathrm{T}) \text { and } \\
\text { dividing by the time dependence of } \\
\text { the stock change factors (D). Here, } \\
\text { country-specific data on land-use and } \\
\text { management are required and } \\
\text { classified into appropriate land } \\
\text { management systems (e.g., cropping } \\
\text { and tillage), and stratified by IPCC } \\
\text { climate regions and soil types. SOC } \\
\text { stocks are estimated for the } \\
\text { commencement and termination of } \\
\text { the inventory time period using } \\
\text { default reference carbon stocks and } \\
\text { stock change factors. }\end{array}$ & $\begin{array}{l}\text { Equation (2) is applied to estimate } \\
\text { carbon stock change in organic soils. } \\
\text { A basic methodology is needed to } \\
\text { stratify planted organic soils by } \\
\text { climate region and assign a } \\
\text { climate-specific annual carbon loss } \\
\text { rate. Land areas are multiplied by the } \\
\text { emission factor and then summed up } \\
\text { to compute annual carbon emissions. }\end{array}$ \\
\hline
\end{tabular}


Table 2. Cont.

\begin{tabular}{|c|c|c|}
\hline $\begin{array}{c}\text { Estimation } \\
\text { Method }\end{array}$ & $\begin{array}{l}\text { Mineral } \\
\text { Soils }\end{array}$ & $\begin{array}{l}\text { Organic } \\
\text { Soils }\end{array}$ \\
\hline Tier 2 & $\begin{array}{l}\text { The same Equation (1) are employed } \\
\text { in Tier 1, but country-specific } \\
\text { information is integrated to better } \\
\text { identify the stock change factors, } \\
\text { reference carbon stocks, climate } \\
\text { regions, soil types, and/or the land } \\
\text { management classification system }\end{array}$ & $\begin{array}{l}\text { The same basic Equation (2) } \\
\text { employed as in Tier 1, but } \\
\text { country-specific information is } \\
\text { incorporated to better specify } \\
\text { emission factors, climate regions, } \\
\text { and/or land management } \\
\text { classification system. }\end{array}$ \\
\hline Tier 3 & $\begin{array}{l}\text { Tier } 3 \text { employs dynamic models } \\
\text { and/or detailed soil carbon inventory } \\
\text { measures as the source for estimating } \\
\text { annual carbon stock changes. } \\
\text { Measurements from models are } \\
\text { computed using coupled equations } \\
\text { that estimate the net variation of soil } \\
\text { carbon. A Tier } 3 \text { method can also be } \\
\text { established using a measurement } \\
\text { method in which a monitoring } \\
\text { benchmark network is sampled } \\
\text { periodically to estimate SOC stock } \\
\text { changes. A much higher density of } \\
\text { benchmark sites will likely be needed } \\
\text { than with models to adequately } \\
\text { represent the combination of land-use } \\
\text { and management systems, climate, } \\
\text { and soil types. }\end{array}$ & $\begin{array}{l}\text { Employs dynamic models and/or } \\
\text { measurement networks, as described } \\
\text { above for mineral soils. }\end{array}$ \\
\hline
\end{tabular}

$\Delta \mathrm{C}_{\text {Mineral }}=$ annual change in carbon stocks in mineral soils, in tons $\mathrm{C} \mathrm{yr}^{-1}$.

$\mathrm{SOC}_{0}=$ soil organic carbon stock in the last year of an inventory time period, in tons $\mathrm{C}$.

$\mathrm{SOC}_{(0-\mathrm{T})}=$ soil organic carbon stock at the beginning of the inventory time period, tons $\mathrm{C}$.

$\mathrm{D}=$ time dependence of stock change factors which is the default time period for transition between equilibrium SOC values, commonly 20 years.

$$
\mathrm{L}_{\text {Organic }}=\mathrm{A} * \mathrm{EF}
$$

$\mathrm{L}_{\text {Organic }}=$ Annual carbon loss from cultivated organic soils in tonnes $\mathrm{C} \mathrm{ha} \mathrm{hr}^{-1} \mathrm{yr}^{-1}$.

$\mathrm{A}=$ Land area of cultivated organic soil in ha. $\mathrm{EF}=$ Emission factor for climate type.

More details on Equations (1) and (2) are provided online at:

https:/ /www.ipcc-nggip.iges.or.jp/public/2006gl/pdf/4_Volume4/V4_14_An2_Su mEqua.pdf (page A2.12)

\subsubsection{Carbon Stock and Flux Estimation for National-Level and Sub-National Jurisdictions}

This section reviews and discusses current methods and approaches used by selected countries, including Canada, to quantify agricultural soil emissions of $\mathrm{CO}_{2}$ and / or $\mathrm{N}_{2} \mathrm{O}$. Even though the IPCC provides standard methodology to estimate GHG emissions from agricultural soils, it also encourages the development of country-specific methodologies for key sources of emissions which can account for regional variability and provide more accurate estimates of GHG emissions (e.g., $\mathrm{N}_{2} \mathrm{O}$ ). These following countries were chosen because GHGs emissions and removals from agricultural soils are the main contributor of the total effect of GHG in the cropland sector. Practices employed to estimate SOC stocks and fluxes for other national-level and sub-national jurisdictions are compared to Canada's NIR. They provide pertinent information on the agricultural sector and its contribution to the status of SOC. 


\subsubsection{European Union Countries}

Agricultural activities in the European Union (EU) 28 Member States generated 470.6 million tons of $\mathrm{CO}_{2}$ equivalent (i.e., $\mathrm{CO}_{2}$ eq) in 2012, corresponding to about $10 \%$ of the total GHG emissions. Half of these emissions were generated from agricultural soils [20]. Despite having detailed national SOC data sets in several EU-28 states, a consistent estimation of SOC stocks at the EU scale remains problematic. To create a new baseline of SOC in EU agricultural soils and to provide a powerful, dynamic tool to orient future European policies for carbon sequestration, a Pan-European model application was established [21], using the SOC model CENTURY [22]. SOC stocks were calculated for 164,000 combinations of soil-climate-land-use combinations, including the main arable crops, orchards and pastures. The SOC model CENTURY was executed with management practices such as fertilization (both organic and mineral), tillage, and irrigation. These data are generated from statistics belonging to the EU statistical office, and verified with the soil inventory and soils sampled from the Land Use/Cover statistical Area Frame Survey, LUCAS [23] which provided ground SOC data measures.

- France: In France, about 53\% of the country is used for agricultural activities [24]. The French National Inventory Report (FNIR) supplies emission data for the entire agricultural sector, which is the second highest emitting sector and accounted for $16 \%$ of the $\mathrm{CO}_{2}$ emissions of the country in 2017 [25]. Agriculture is the leading sector in terms of $\mathrm{CH}_{4}$ and $\mathrm{N}_{2} \mathrm{O}$ emissions with $69 \%$ and $85 \%$, respectively. The only sources of $\mathrm{CO}_{2}$ on agricultural soils are caused by lime applications to reduce soil acidity and from spreading urea fertilizers. The methodology adopted by the country for counting SOC changes is a Tier 2 based on the 2006 IPCC guidelines, where emissions are calculated from inputs including the amounts of post-harvest residues amounts, estimated crop-specific area burned, and the amounts of dry matter contained in these residues. Of the EU-28 countries, France reported the highest SOC stocks as predicted using the CENTURY model.

- United Kingdom (UK): More than three-quarters of the land area in the UK is used for agriculture in 2019 (i.e., $352 \mathrm{Mt} \mathrm{CO}_{2}$ eq) and agricultural contributions to the total GHG emissions was $5.7 \mathrm{Mt} \mathrm{CO}_{2}$ eq (UK 2020). Emissions of $\mathrm{N}_{2} \mathrm{O}$ from agricultural soils are a key category in the UK GHG inventory [26], and they have substantially declined between the 1990 and 2019 reporting period because of reduced use of synthetic fertilizers and changes in agricultural management practices (i.e., reduced till). Direct emissions of $\mathrm{N}_{2} \mathrm{O}$ from agricultural soils are estimated using the 1997 IPCC recommended methodology and incorporate UK-specific parameters (e.g., crop residue returned to soils, cultivation of organic soils, manure deposited by grazing animals, the use of synthetic fertilizers). Soil organic carbon changes are estimated using a matrix of land-use change (i.e., derived from land surveys) linked to the Rothamsted soil C model, Roth-C [27], which can simulate soil carbon gains or losses as a function of management practices. The Roth-C model is conceptually similar to the IPCC approach, with the important difference that changes in soil carbon stocks over time are modeled as nonlinear using an exponential function. To apply the model, data are required from the initial and the final land-use to estimate the change in soil $\mathrm{C}$ stocks during a transition period. These are calculated for each land use category as area-weighted averages by major soil types and by country (i.e., Scotland, England, and Wales) within the United Kingdom. The SOC stock changes reported for the NIR (UNFCCC) using this methodology include means and estimates of uncertainty based on a Monte Carlo approach, and computed separately for England, Scotland, and Wales. For Northern Ireland, estimates of SOC stocks have been obtained using an IPCC-based approach as currently no land-use change matrix is available.

The DeNitrification and DeComposition model (DNDC; [28]) has been used to estimate $\mathrm{N}_{2} \mathrm{O}$ emissions from UK agricultural soils. UK-specific, country-level characteristics for soils, crops, livestock and farming practices, and daily climate records are used as input data. Model validation was done using the available, but limited, field data. The DNDC- 
based $\mathrm{N}_{2} \mathrm{O}$ estimates from indirect emissions and agricultural practices were about $40 \%$ lower than the estimates made using the IPCC default method. The Tier 1 methodology from the IPCC guidelines also has been applied also to calculate emissions from agricultural soils for the UK overseas territories and Crown dependencies.

- Germany: Agriculture is an important component of the German economy and represented, in 2016, about $47 \%$ of the total land area was under agriculture with two-thirds planted to annual crops. Fertilizer use and livestock are the major sources of GHG emissions $\left(\mathrm{N}_{2} \mathrm{O}\right.$ and $\left.\mathrm{CH}_{4}\right)$ in the agriculture sector. Germany uses a simulation modeling approach for estimating $\mathrm{N}_{2} \mathrm{O}$ emissions from agricultural soils. Specifically, the DNDC model is used for integration of the complex interactions among primary drivers, biogeochemical reactions and soil environmental factors. Input parameters for the model include crop type, soil properties (e.g., bulk density, texture, $\mathrm{pH}$, and soil OM content), land management practices, and daily climate data. The DNDC model has been used for regional estimates of $\mathrm{N}_{2} \mathrm{O}$ emissions and predicts slightly higher $(10 \%)$ estimates compared to those based on the IPCC default method. Although $\mathrm{CO}_{2}$ emissions from organically managed soils are an important component of German agriculture, methodology for estimating these emissions is still in development. Soil carbon stocks for annual and perennial cropland have been estimated using remotely sensed data, soil data; emission factors have been derived from the scientific literature.

\subsubsection{United States of America (USA)}

Agricultural land accounts for about $46 \%$ of total land area in the USA and is comprised of arable land (19\%), intensive pasture (6\%), and rangeland (21\%). Agriculture activities were responsible for $9.9 \%$ (i.e., $6,68 \mathrm{Mt} \mathrm{CO}_{2}$ eq) of $2018 \mathrm{GHG}$ total country emissions [29]. Emissions from the agricultural sector are mainly from agricultural soils, rice production, and livestock. Nitrous oxide was the largest source of GHG emissions, accounting for $76.9 \% . \mathrm{CO}_{2}$ emissions from liming and urea fertilization represented $0.2 \%$ of total $\mathrm{CO}_{2}$ emissions. Important trends affecting GHG emissions from agricultural soils include reduction in tillage intensity, increase in cropping intensity and set-aside of marginal lands in conservation reserves.

The USA uses a modified version of the IPCC default methodology to estimate soil C stock changes with U.S.-specific reference $C$ stocks and stock change factors. Activity data are stratified by IPCC-defined climate and soil types. The National Resources Inventory (NRI) is the primary source of land-use and management data. The NRI records crop type, land-use, and other information (e.g., soil type) on more than 400,000 permanent inventory points on agricultural lands. Supplemental data, including county-level tillage practices, fertilizer use, and manure production, are included in the inventory. The $\mathrm{N}_{2} \mathrm{O}$ emissions from agricultural soils are estimated using a simulation-based approach with the DAYCENT model [30-32].

The DAYCENT model is used to predict crop growth across the USA and examines both soil nitrogen and carbon dynamics. Information on crop type for DAYCENT is obtained using Remote Sensing techniques developed by NASA. Specifically, the NASACASA production algorithm $[33,34]$ uses MODIS satellite imagery (i.e., moderate spatial resolution of $250 \mathrm{~m}$ ) Enhanced Vegetation Index (EVI) products aboard the Terra and Aqua Satellites. This model uses the soil C modeling framework developed in the CENTURY model [22], but has been refined to simulate dynamics at a daily time-step [29]. Annual changes are computed dynamically as a function of inputs of organic $C$ to soil (e.g., crop residues, manure). Emissions of $\mathrm{CO}_{2}$ from organic matter decomposition are controlled by climate and soil factors as well as management practices. The DAYCENT model simulates all major field crops (e.g., wheat, other small grains, corn, wheat, soybean, sorghum, and cotton) as well as hay and pasture (i.e., alfalfa, clover, and grass). The same sources of input data as in the IPCC-based methodology are used for management variables, and include tillage, fertilization, irrigation, drainage, and manure addition. Although both methods attribute $C$ gains to conservation set-aside and reduced tillage, the simulation approach 
also accounts for the long-term trend of increasing crop productivity, which is not captured by the IPCC method.

The U.S. modeling approach using DAYCENT has several advantages over the empirical IPCC default method in that it can better capture the interaction between different management conditions, including fertilization and manuring practices, soils, and varying climate. A major challenge is in deriving activity data (i.e., such as synthetic fertilizer and manure nitrogen inputs) at a suitable spatial scale, since existing fertilizer use databases are aggregated at the county-level. Comparative studies have shown that estimates obtained using the DAYCENT model were 10 to $15 \%$ lower than with the IPCC method and had greater internal variability due to the inclusion of weather effects in the simulation [35]. The largest factor contributing to this difference is that DAYCENT predicted lower emissions under $\mathrm{N}_{2}$-fixing crops compared with the IPCC method. In addition to the USA NIR Emissions and Sinks produced by U.S. EPA, many states have their own inventories to keep track of GHG emissions from each sector at the state level. In this study, we present agricultural GHG emissions for two states, California and Michigan, because of the importance of agriculture to their respective economies.

- California: Agriculture is an important sector in California's economy [36] and accounts for $7.6 \%$ of the state's total GHG emissions [37]. Of the 43 million acres used for agriculture, 27 million acres are in cropland. The California GHG Emission Inventory focused only on emission sources and did not consider SOC stocks or fluxes. These sources were broad and included emissions from fuel combustion, livestock, fertilizer, soil preparation and disturbance, and crop residue burning. Calculation methodologies to account the state's total GHG emissions follow the 2006 IPCC guidelines. Therefore, to ensure comparability with international inventories, the Californian GHG reporting method is based on both an IPCC process-oriented classes and the IPCC classification. The only other data sources listed that may pertain to agricultural emissions are the U.S. EPA and the California Department of Food and Agriculture.

- Michigan is after California, the second largest agricultural state economy in the U.S. with 10 million acres of farmland [38] with the agriculture sector accounting for about 3\% of the Michigan's total GHG emissions. Like the California GHG Emission Inventory, agriculture is not the major focus or contributor to total GHG emissions in Michigan. In contrast to California, Michigan does consider agricultural SOC stocks and soil carbon emissions in its GHG inventory. Net carbon fluxes from agricultural soils were estimated by researchers at the Natural Resources Ecology Laboratory at Colorado State University and are reported in the "US Inventory of Greenhouse Gas Emissions and Sinks" and the "US Agriculture and Forestry Greenhouse Gas Inventory" [39]. The primary GHG emissions considered from agricultural soils are for $\mathrm{N}_{2} \mathrm{O}$ and $\mathrm{CO}_{2}$ and are estimated simultaneously using the Tier 3 approach developed by the IPCC 2006.

\subsubsection{Australia}

According to the 2015 World Bank collection of development indicators, about $48 \%$ of the Australian land is under agricultural and pastoral use. The Department of the Environment and Energy acts as the only inventory agency [40] and is responsible for all aspects of inventory coordination, including activity data collection, emissions estimations, compilation of the inventory report, and publication and submission of the inventory to the UNFCCC [40]. In 2018, agriculture accounted for approximately 13\% of Australia's total GHG emissions. Agricultural soils and manure management contributed to 3\% and 1\%, respectively of total agricultural emissions mainly as $\mathrm{N}_{2} \mathrm{O}$ from the application of fertilizers and the use of nitrogen fixing crops and pastures.

The Australian National GHG Accounting System is based on resource inventories, field studies, modeling, and remote sensing. Carbon stocks are estimated using the same systems and methods as those in the National GHG inventory, which use methods consistent with the guidelines of the IPCC 2006 [16]. These GHG accounts are created using a 
verified model-based accounting system, operating at highly disaggregated spatial and temporal scales (i.e., $25 \mathrm{~m}$ ). Australia's Tier 3 approach to estimating $C$ stock changes is based on an advanced model, the Full Carbon Accounting Model, FullCAM [41], and used in conjunction with satellite imagery and other spatial inputs to determine the carbon stock change on forest and agricultural systems. The FullCAM consists of three sub-models: a carbon accounting model for cropping and grazing systems (CAMAg) that calculates crop residue $\mathrm{C}$ inputs; a crop residue decomposition model; and Roth-C model which has a crop residue decay component as one of the pools of SOC. The three sub-models can be run independently or in an integrated fashion to provide estimates of GHG emissions and removals in all carbon pools (i.e., biomass, dead OM, and soils) and for all GHGs (e.g., $\mathrm{CO}_{2}, \mathrm{CH}_{4}$, and $\mathrm{N}_{2} \mathrm{O}$ ). The FullCAM model provides a linkage between these sub-models. CAMAg reflects the management impacts on $\mathrm{C}$ accumulation and allocates crop biomass to various plant product pools and to decomposable and resistant crop residues [42]. Changes in agricultural SOC stocks are estimated using the Roth-C model [27], based on soil type, land use and management history, and residue inputs from different cropping systems. The model has been calibrated against long-term field measurements and verified using paired sites (undisturbed vs. cleared sites) in areas of major land-use change. To estimate SOC stock changes with the Roth-C model, the soil carbon component of FullCAM requires spatial soils data that describes the soil type, clay content, and the pre-disturbance $C$ content. Data describing the spatial extent of soil types within Australia as defined by the Australian Soil Classification.

In addition to soil type data, a national SOC map was produced by Viscarra-Rossel et al. [43] using spatial analysis techniques using data from Australia's National Soil Carbon Research Program (SCaRP), the National Geochemical Survey of Australia (NGSA) and the ASRIS. SOC stocks to a depth of $30 \mathrm{~cm}$ were predicted at an approximately $90 \mathrm{~m}$ grid resolution for the entire Australian landmass. This map formed the basis for baseline soil $C$ stocks used by the Roth-C model [44]. Other maps describing the spatial extent of measurable soil $\mathrm{C}$ pools were also produced, including particulate organic carbon, humic organic carbon, and resistant organic carbon. These maps were produced using 400 soil data points and a methodology similar to that used to produce the baseline SOC map. These measurable SOC pools were used to initialize the Roth-C model in place of the conceptual C pools normally used within Roth-C. The spatial distribution map of soil clay content for all Australia, as part of the Soil and Landscape Grid of Australia-wide Soil Attribute Map series, was produced using soil attribute data from existing databases and a piecewise linear model that considered 50 environmental covariates representing climate, biota, terrain, soil, and parent material.

\subsubsection{New Zealand}

Agriculture is the primary economic activity in New Zealand with intensive and extensive pastoral systems predominant [45]. Only $1 \%$ of the land area is devoted to annual crops. In 2015, agriculture was the major contributor (50\%) to total national GHG emissions. Methane (i.e., from enteric fermentation) and $\mathrm{N}_{2} \mathrm{O}$ (from soils) were the largest sources of the emissions within the agriculture sector, contributing $73 \%$ and $21 \%$, respectively. The Ministry for the Environment acts as the inventory agency and is in charge of the coordination, compilation of report and publication and submission of the inventory to the IPCC.

New Zealand uses a soil Carbon Monitoring System (CMS) to account for changes in soil C stocks, which is a country-specific database [46]. These changes are mostly due to land cover changes (e.g., conversion of grazing land to plantation forestry). The soil CMS is based on an empirical model, similar in concept to the IPCC approach. New Zealand uses a Tier 2 method for accounting SOC stock changes in mineral soils, which are triggered by changes in land-use, and uses a Tier 1 for organic soils. The IPCC default 20-year equilibrium period is used for estimating SOC stock additions and removals to a depth of $30 \mathrm{~cm}$ due to land-use change in the absence of country- and land-use-specific 
data [47]. The soil CMS model uses three data layers (i.e., land use, climate and soil types), for which steady state soil carbon stocks are assigned using georeferenced soil carbon measurements. New Zealand's approach to estimating SOC changes does not explicitly ponder the impact of farm management practices on soil carbon stocks. Instead, it assumes that the driving force regulating SOC stocks in mineral soils is land-use change. Other factors influencing soil carbon stocks, including soil type, climate, and erosivity, are assumed to remain constant at the temporal scale of the inventory time series [47]. Thus, the only cropland management change considered when estimating soil $\mathrm{C}$ stock changes for the GHG inventory is the change between annual cropland to perennial cropland.

\subsubsection{Japan}

Japan has limited arable land (approx. 13\%) suitable for agriculture. Rice is by far the most important crop planted on the best agricultural land (approx. an area of 1.55 million hectares in 2012/2013); and other crops grown include wheat, soybeans, and barley [48]. Japan's emissions in the 2019 year dropped to 1.2 billion $\mathrm{Mt} \mathrm{CO}_{2}$ eq. The agricultural sector accounted for $2.5 \%$ of total GHG emissions in 2015 of which $\mathrm{N}_{2} \mathrm{O}$ emissions accounted for $0.4 \%$ (excluding LULUCF). The largest sources of agricultural emissions (i.e., $\mathrm{CH}_{4}$ ) were from rice farming, accounting for $41 \%$, enteric fermentation (i.e., $\mathrm{CH}_{4}$ ) for $22 \%$, and agricultural soils $\left(\mathrm{N}_{2} \mathrm{O}\right)$ because of nitrogen-based fertilizer applications for $16 \%$ of total GHG emissions. The Tier 2 method in accordance with the decision tree of the 2006 IPCC guidelines [16] are employed to estimate $\mathrm{N}_{2} \mathrm{O}$ emissions. The country inventory is reported in agreement with the UNFCCC Guidelines on Annual Inventories reporting. Japan's estimation methodologies of GHG inventories are principally in line with the 2006 IPCC guidelines [16] and both Tier 1 and 2 approaches are used. The cropland remaining cropland subcategory describes SOC stock changes in cropland which has remained as cropland in the past 20 years. Soil carbon stock changes at the national level are estimated as the sum of measurements conducted at each local area. Carbon stock changes in live biomass are estimated for the carbon stock change in perennial tree crops in accordance with the 2006 IPCC guidelines [16]. Carbon stock changes in dead OM are considered as zero by applying the Tier 1 method. The latter assumes that the carbon stock does not change. In the case of mineral soils, Carbon stock changes are determined by applying a Tier 3 modeling approach using the Roth-C model. On-site $\mathrm{CO}_{2}$ emissions from drained inland organic soils planted to rice fields and upland fields are both estimated.

\subsubsection{Canada}

In 2015, estimated 7\% of the total land area in Canada was under agriculture with two-thirds used for crops and improved pasture. Canada is publishing EO satelliteacquired data for cropland cover under its Annual Crop Inventory information (Figure 1). Environment Canada is the single national entity responsible for the preparation and submission of the annual National Inventory (NIR) to the UNFCCC. Canada's total GHG emissions in 2017 were estimated at $716 \mathrm{Mt} \mathrm{CO}_{2}$ eq [49]; agricultural activities accounted for $8.4 \%$ of total GHG emissions. The main GHGs emitted from agricultural activities include $\mathrm{CO}_{2}$ emitted from decay of soil organic matter, $\mathrm{CH}_{4}$ emissions associated with cattle production and livestock manure storage, and $\mathrm{N}_{2} \mathrm{O}$ emissions from soil and soil management (i.e., nitrogen fertilizers and animal manures). The IPCC Tier 1 method for $\mathrm{N}_{2} \mathrm{O}$ and the CENTURY model for $\mathrm{CO}_{2}$ are used for estimating GHG emissions from agricultural soils for the NIR. The CENTURY model has been calibrated for Canadian conditions and uses Soil Landscapes of Canada (SLC) polygons as the basic geographic unit. There are 3393 SLC georeferenced polygons in the entire country with agricultural activities and they contain 12,909 unique soil landscape combinations, according to the Canada's NIR [50]. The SLC polygons have an agricultural area in the range of 1000 to 100,000 ha and are suitable for digital mapping at the scale of 1:1,000,00. The Agricultural Production Census (i.e., Statistics Canada) is the main source for data describing on-farm management practices within the country. 


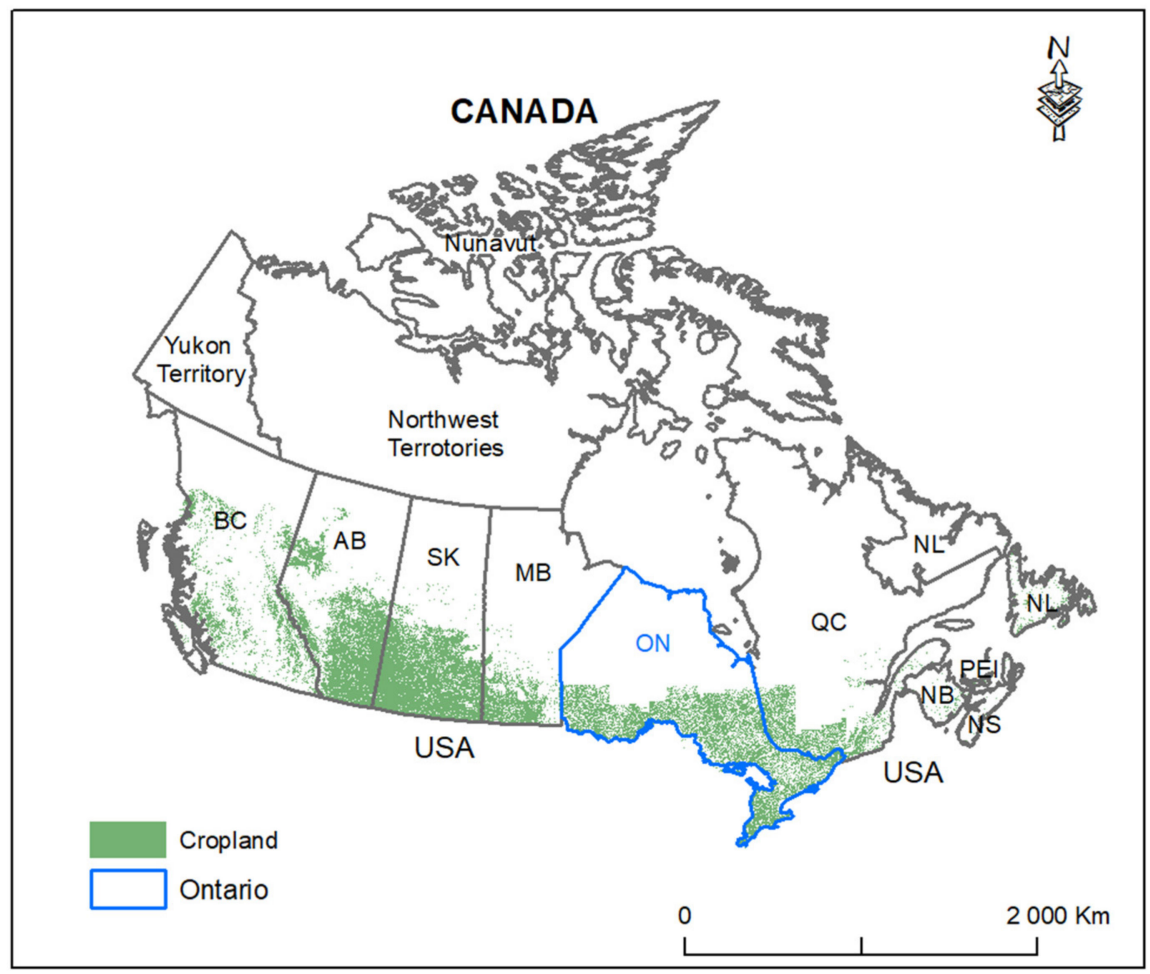

Figure 1. Cropland distribution (green area) in Ontario and the other Canadian provinces. $\mathrm{AB}=$ Alberta, $\mathrm{BC}=$ British Columbia, $\mathrm{ON}=$ Ontario; $\mathrm{QC}=$ Quebec; $\mathrm{MB}=$ Manitoba, $\mathrm{SK}=$ Saskatchewan; $\mathrm{NB}=$ New Brunswick; NS= Nova Scotia; NL= Newfoundland and Labrador; PEI= Prince Edward Island. Cropland data were generated from the 2020 annual space-based crop inventory for Canada.

The inventory of the agricultural land sector is included under the cropland remaining cropland (CRC) categories. It contains $\mathrm{CO}_{2}$ emissions from cultivation of organic soils, $\mathrm{CO}_{2}$ emissions/removals in mineral soils, and $\mathrm{CO}_{2}$ emissions/removals resulting from changes in woody biomass from crops. Mineral and organic soils account for $99 \%$ and $1 \%$ of the total cropland areas, respectively. Canada's inventory uses an enhanced Tier 2 approach for estimating $\mathrm{CO}_{2}$ emissions from, and removals by, mineral soils generated by changes in land management practices. Thus, specific cropping systems and soil management practices determine SOC stocks and whether the amount of SOC stored in a soil is increasing, decreasing, or remaining stable. The SOC retained in soil represents the difference between the rate of inputs from crop residues and losses through SOC decomposition. Thus, if no change in management practices occurs, the soil organic $C$ stocks are assumed to be in a steady state (i.e., the SOC stock change is zero). An SOC change factor is used to calculate carbon emissions and removals for the inventory. The SOC change factor $(\mathrm{F})$, which is specific for each combination of SLC polygons and land management change (LMC), is multiplied by the land area affected by the change. The SOC change factor is the average rate of SOC change per year and per unit area of LMC and it is derived using a modeling approach (CENTURY). The annual $\mathrm{CO}_{2}$ emissions/removals by mineral soils undergoing a specific LMC are expressed as:

$$
\Delta \mathrm{C}=\mathrm{F} \times \mathrm{A}
$$

$\Delta \mathrm{C}=$ change in $\mathrm{SOC}$ stock for inventory year, $\mathrm{Mg} \mathrm{C} ; \mathrm{F}=$ average annual change in $\mathrm{SOC}$ subject to LMC in $\mathrm{Mg} \mathrm{C} /$ ha/year; $\mathrm{A}=\mathrm{LMC}$ area in ha.

Historically, provincial and territorial GHG emissions have varied significantly as a result of population, energy sources and economic structure. Alberta and Ontario have been the highest emitting provinces, whereas the agriculture sector in the combined three territories generated less than $0.5 \%$ of the total Canadian's GHG emissions. A detailed 
description of Canada's provinces and territories of the agricultural soils sector GHG emissions is provided in Figure 2. Although the Canadian government is responsible for preparing the NIR [50] each year under its UNFCCC reporting requirement, the NIR encourages provinces and territories to develop inventories more appropriate for their own conditions and data availability [51]. However, development of such inventories requires considerable time and resources, including testing and validation, before implementation. Consequently, relatively few provinces have implemented specific systems. The following sections outline provincial and territorial emissions and the specific methods developed to estimate carbon emissions and removals $\left(\mathrm{CO}_{2}\right.$ and/or $\left.\mathrm{N}_{2} \mathrm{O}\right)$ from agricultural soils.

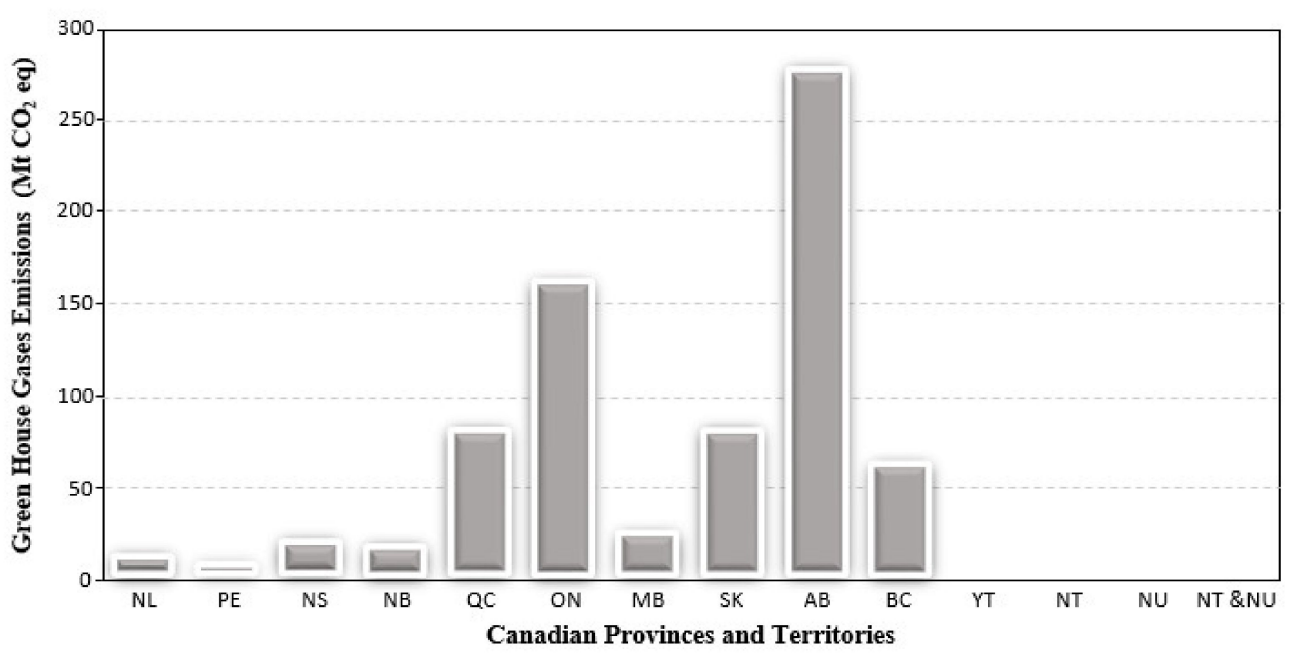

Figure 2. Greenhouse gas emissions by province and territory in 2017. Province and territory codes are shown in Figure 1.

- The province of Québec (QC) has 29,000 farms corresponding to $15 \%$ of Canada's total farm numbers [52]. In 2017, Québec accounted for 11\% of Canada's total GHG emissions (79 $\mathrm{Mt} \mathrm{CO}_{2}$ eq) and agriculture represented 9.2\% of Québec's total GHG emissions. Emissions from the agriculture sector increased by $4.2 \%$ during the period from 1990 to 2013. Agricultural soils were the main source of these emissions (43\%), followed by manure management $(31 \%)$, and livestock $(27 \%)$. Farming practices and agricultural soil management, such as the use of synthetic fertilizers, are responsible for GHG emissions from farmland. $\mathrm{CO}_{2}$ and $\mathrm{N}_{2} \mathrm{O}$ are the main gases emitted from agricultural soils with $77.7 \%$ and $5.3 \%$, respectively.

- The Atlantic Provinces (i.e., Nova Scotia (NS), New Brunswick (NB), Prince Edward Island (PEI), and Newfoundland and Labrador (NL)) encompasses about $3.9 \%$ of Canada's total number of farms was reported in the Atlantic Provinces [53]. NS had the highest number of farms with 3478, followed by NB, PEI, and NL with 2255; 1353; and 407 farms, respectively. NS's Climate Change Action Plans focus mainly on the energy and transportation sectors to meet their GHG targets, and do not consider GHG emissions from the agriculture sector or from soils. In 2017, agriculture accounted for $2 \%$ of NB's GHG emissions and were mainly from livestock. PEI generates less than $1 \%$ of Canada's total GHGs, with agriculture contributing $23 \%$ of the provincial total from livestock, manure and synthetic fertilizer use being the main sources. $\mathrm{N}_{2} \mathrm{O}$ is the main GHG emitted from PEI's agricultural soils. Agricultural land accounted for less than $2 \%$ of NLs' GHG emissions with about $13 \%$ of these emissions from agricultural soils. NS produces $2.2 \%$ of Canada's total GHG. Detailed information of the Atlantic Provinces GHG emission and removal estimates from agricultural soils are contained in Canada's GHG inventory as these provinces do not have their own detailed inventory reporting systems.

- The Prairie Provinces (i.e., Alberta (AB), Saskatchewan (SK), and Manitoba (MB)) contain 90,000 farms, which represent 46.5\% of Canada's total according to the 2016 
Census. AB has the highest number of farms with 40,638 , followed by Saskatchewan with 34,523 and Manitoba with 14,791. The main source of the GHG emissions from agricultural soils in the Prairie Provinces is the application of synthetic fertilizers. In 2017, GHG emissions from the agriculture sector in $\mathrm{AB}$ were estimated at $22 \mathrm{Mt} \mathrm{CO}_{2}$ eq, which was $8 \%$ of AB's total GHG emissions and accounted for $30 \%$ of Canada's agricultural emissions. About half of $\mathrm{AB}^{\prime}$ s agricultural emissions are from crop production and management practices (e.g., fertilizer use, tillage practices) whereas the remainder is from livestock production and from manure management. The main GHGs emitted by agriculture are $\mathrm{N}_{2} \mathrm{O}$ and $\mathrm{CO}_{2}$. In 2015, SK accounted for $10 \%$ of Canada's total GHG emissions (75 $\mathrm{Mt} \mathrm{CO}_{2}$ eq). Agriculture accounted for $24 \%$ of the provincial GHG emissions with $\mathrm{N}_{2} \mathrm{O}$ being the main GHG emitted. Agriculture was the main source of the GHG emitted in MB in 2015, accounting for 31\% of the total. These emissions were from agricultural soils (48\%), livestock production $(39 \%)$, and manure management $(13 \%)$. $\mathrm{N}_{2} \mathrm{O}$ and $\mathrm{CH}_{4}$ were the main GHGs emitted, and they resulted from applications of synthetic fertilizers (soil management) and anaerobic manure storage (manure management), respectively.

- British Columbia Province (BC) has 17,528 farms which represent 9\% of Canada's total farms according to the 2016 Census of Agriculture. In 2015, the agriculture sector accounted for $3.7 \%$ of BC's total GHG emissions. Agricultural soils were the third main source of these emissions (18.4\%), after livestock production (60.4\%) and manure management $(20.2 \%)$. $\mathrm{N}_{2} \mathrm{O}$ is the major GHG emitted from agricultural soils. With its own provincial greenhouse Gas inventory, estimates for most sectors, including cropland, are taken from the NIR and Canada's Submission to the UNFCCC. The emissions from cropland are presented as memo items and is not currently counted towards the total inventory of the province.

- The province of Ontario (ON) has about $26 \%$ of Canada's total farms according to the 2016 Census [53]. The emissions from the agriculture sector have remained constant since 1990. Ontario does not currently include GHG emissions and removals from the land use sector in its GHG inventory or in GHG reduction targets. As of 2018, Ontario does not produce its own land use carbon inventory (LUCI). GHG emission estimates for the province are mainly derived from the federal NIR. In 2012, the agricultural sector in Ontario was responsible for 6\% of total GHG emissions (6.5\% below 1990 levels).

\subsection{Comparison of National GHG Inventories and Models Used in Accounting Carbon Stocks}

\subsubsection{Canada's NIR vs. Other Countries}

Although many countries including Canada use a Tier 2 based approach for estimating SOC stock changes in minerals soils on cropland and a Tier 1 approach for estimating C emissions from organic soils, some significant differences exist between the approach used by Canada and the other countries: (1) Canada's activity data are linked to a geographical boundary (i.e., SLC polygons) and is not spatially explicit. Many countries (e.g., New Zealand) use activity data (i.e., land-use) that are spatially explicit. (2) Canada takes a process-based approach to estimate SOC stock changes in mineral soils, where initial estimates of steady state $C$ stock are not as important as the influence of land management change (i.e., LMC) on the steady state stocks. In contrast, New Zealand take a stock-based approach where the SOC stocks are estimated at two discrete points in time and the change in SOC stocks over time is assumed to be linear. One fundamental result of this difference in stock change methods is that Canada does not explicitly estimate initial SOC stocks.

Canada uses the CENTURY model to estimate a baseline initial C stock for all cropland prior to LMC. Estimates of SOC stock change in mineral soils due to a LMC are obtained from simulating the change in specific management practices. This is accomplished via stock change factors that are specific to the unique soil-climate-management conditions occurring within an SLC polygon (the smallest spatial unit of analysis). In contrast, New Zealand relies on estimates of the initial and inventory year $C$ stocks to calculate the 
change in SOC stocks over time. For example, if New Zealand were to consider the impact of cropland management on C stocks (e.g., tillage), significant resources would be required to collect empirical soil data to calibrate the soil CMS and estimate SOC stocks for all combinations of soil type-climate-management categories. Other differences between Canada and New Zealand are in term for erosion; i.e., Canada does not account for erosion when calculating SOC stock changes; whereas New Zealand incorporates a slope $\mathrm{X}$ rainfall factor to account for the influence of erosion on estimates of SOC stock changes. Canada stratifies the cropland land-use category by climate and soil type. It considers management when incorporating activity data into the CENTURY model to determine stock change factors. New Zealand further stratifies the cropland category based on management to consider annual and perennial cropland, as well as soil type and climate data. Most countries (e.g., Australia), including Canada, use a Tier 1 approach to estimate $\mathrm{C}$ emissions from organic soils. Canada does not stratify the $\mathrm{C}$ emission factor for organic soils by climate whereas other most countries do. For example, New Zealand stratifies its organic soils into two groups based on climate. Like Canada, none of the cited countries attempt to estimate emissions from soil inorganic $C$ parent material (i.e., carbonate-containing minerals).

2.2.2. Recommended Ontario-Specific Solution to Estimating C Emissions and Removals in Cropland

Although the Tier 3 approach can produce more accurate estimates of SOC stock changes than either the Tier 1 or Tier 2 approaches, we believe this approach might not be appropriate for an Ontario-specific solution to estimating $\mathrm{C}$ emissions and removals in the cropland sector. It is unlikely that the first iteration of Ontario's GHG inventory will include Tier 3 methodologies due to the resources and time required to undertake an empirically based calibration, validation, and initialization of an Ontario-specific model. A combination of the approaches taken by Canada and other countries (e.g., New Zealand and Australia) would allow Ontario to lead in the development of an approach that more accurately estimates SOC stock changes in cropland soils. Canada's current Tier 2 approach for estimating the effect that LMC has on the SOC pool could be adopted and combined with a spatially explicit approach as used by other countries (e.g., New Zealand) for defining its land-base and activity. High-resolution cropland land-base information and management data in the form of the second-generation Ontario Agricultural Resource Inventory is readily accessible. This georeferenced database provides land management activity data at the field-scale and allows inventory compliers to track LMC and land-use change at high temporal and spatial scales (i.e., on a field-by-field and year-by-year basis). Furthermore, high-resolution topographic data for key cropland areas in the form of LiDAR-derived digital elevation models are available. These datasets allow incorporation of the influence of erosivity into inventory estimates of SOC emissions and removals from cropland.

\section{Synthesis of the Main Gap Analysis}

In this study, we have identified four main gaps in the methodology used by the Canada's NIR for estimating GHG emissions from the cropland sector.

\subsection{Modeling Approach}

Computer simulation models allow prediction of different agricultural management scenarios and climate change on SOC stocks. In particular, these models can compare different soil management practices (e.g., reduced tillage), the influence of crop yield increases (i.e., residue inputs) with improved varieties, changes in agronomic practices over time (e.g., fertility, cropping systems), and changes in climate due to global warming. In Canada, the CENTURY model has been used to predict soil C stocks for the NIR. This model describes the entire agricultural ecosystem, incorporating crop growth, plant residue inputs and tillage management effects on plant residue decay and on the dynamics of the constituent pools of SOM. A modified version of the CENTURY model was selected by several countries (e.g., EU, USA, Serbia, Bosnia and Herzegovina, Croatia, Montenegro, 
Albania, Macedonia, Denmark, and Norway) as being most suitable because of its ability to simulate the effects of the main management practices in agricultural fields (tillage, fertilization, grazing, etc.), and to simulate mixed management systems. In addition, computational time was reduced when modeling large numbers of management combinations because of the monthly time-step.

Two other soil-only Process Models applied in Canada to predict SOC stocks in Canadian agricultural soils are Roth-C and the Introductory Carbon Balance Model (ICBM) [54]. Roth-C has an advantage in that Plant-C inputs are easy to capture as they are added externally (i.e., empirical measurement). Satellite images or drone data could be used for obtaining site-specific crop C inputs. Both Australia and Japan use their own modified versions of Roth-C. The ICBM model, which has two SOC pools, is considered too simplistic and does not consider effects of soil texture on regulating SOC dynamics.

Even though Canada and other countries use the CENTURY model to estimate an initial baseline $C$ stocks for all cropland, this model remains too complicated to implement in most developing countries (i.e., African countries) because of the limited or inexistent required input datasets. In these cases, an alternative modeling approach for prediction of SOC changes on agricultural land can be using an improved version of the Roth-C model. This model is also promising because of its simplicity and the availability of input data.

\subsection{Model Input Data}

Although this study supports and recommends continuing the use of the CENTURY model for estimating SOC stocks and SOC changes due to management, we have targeted input gaps which require solutions. The two most important gaps are manure management and soil erosion. Indeed, the effects of manure application and management on $\mathrm{C}$ cycling is not yet included in the Canada's NIR; manure is included in $\mathrm{N}_{2} \mathrm{O}$ cycling but the $\mathrm{C}$ component is not yet considered. Soil erosion (both redistribution and deposition) also is not included in C stock changes or in GHG emissions, and these factors have a significant influence on field-level SOC stocks. There is currently a lack of understanding of the effects of animal manure management and soil erosion on net GHG emissions, so a comprehensive review of the literature is necessary for these factors to be incorporated into the CENTURY model.

In terms of existing data inputs, many of the input parameters and calibration factors are not necessarily generalized for applicability within Ontario. Model performance could be improved by tuning of input parameters specific for Ontario soil types, soil management practices, cropping systems and climatic conditions. For example, the parameters used to calibrate the crop growth sub-model in the Century model need to be specific for each crop and for each region of Ontario. Therefore, for estimations of crop C inputs, Ontario should use regionally specific crop yields, and include both the quantity and quality (chemical properties) of the residues and how they are managed (left on the field or baled and removed).

\subsection{Geographic Units and Input Data}

As noted above, the CENTURY model simulation in Canada is carried out for each SLC polygon. A SLC polygon is described by a standard set of attributes derived from Census of Agriculture data, with areas ranging from 1000 to 100,000 ha. Given the small scale (i.e., 1:1,000,000) described by a SLC polygon, it is not possible to obtain small/medium spatial resolution data, nor is it possible to correlate GHG drivers (i.e., topography, soil type, management practices) within a single polygon because these data are aggregated. A raster-based spatially explicit modeling approach which uses EO data (e.g., remote sensing maps) is a promising alternative. Information on agricultural soils/crops and Enhanced Vegetation Indices could be derived from satellite imagery (e.g., MODIS with moderate resolution of $250 \mathrm{~m}$ ) and inputted to the model to produce maps of SOC stocks on a raster basis. 
A recent development in digital soil mapping includes the use of remotely sensed covariates and machine learning techniques to study space-time variation of SOC stocks [55]. Because of its importance for spatial prediction of SOC in topsoil, these techniques could play a major role in LUCI implementation. The Canadian Annual Crop Inventory information published cropland cover (i.e., shown in Figure 1) can be of benefit LUCI implementation. We believe that a non-spatially explicit approach can impose limits on properly defining cropland areas and conversions between other land use areas and cropland. This has been acknowledged, for instance, in Australia's most recent NIR where planned improvements are underway to develop a fully spatially explicit time series of land-use maps to apply land representation to all land-uses. Such improvements would enable reporting of separate activity data and emissions estimates for all conversion categories.

The main benefit of this approach to LUCI would be its ability to represent land-use categories in the LULUCF sector in a spatially explicit way. As stated in the 2006 IPCC guidelines, "this analytical capacity can improve emissions estimates by better aligning land-use categories (and conversions) with strata mapped for classification of carbon stocks and emission factors by soil type, [and] vegetation type. This may be particularly applicable for Tier 3 emission estimation methodologies" (IPCC, 2006; [16]). We believe that the shift to a spatially explicit description of cropland area within Ontario and conversions between other land use categories and the cropland category would represent a great opportunity to improve cropland emission and removal estimates for Canada's NIR.

\subsection{Ground-Truth Program and Farmer Collaboration}

Given that levels of SOC stocks respond slowly to changes in agricultural management practices, several years of monitoring are required to detect changes in stocks by current analytical procedures. Compared to other countries, Canada's NIR uses a relatively small number of long-term experimental sites to calibrate and validate the CENTURY model. Ontario's LUCI will need to put in place a ground-truth program to deal with uncertainties due to spatial variability and regional climates, and to calibrate the CENTURY model. These selected sites need to be where management practices, soil conditions and cropping practices can be carefully monitored over a long period. At these sites, soil C stock sampling should be conducted every 5 years, including measurements of soil bulk density, and samples analyzed following reference procedures (i.e., high temperature combustion) after removal of inorganic $\mathrm{C}$. Given the important role of nitrogen in decomposition and SOC stabilization, total $\mathrm{N}$ stocks should also be measured.

In addition to the existing long-term sites in Ontario [56,57], we recommend further establishment of an extensive network of long-term field sites throughout Ontario through farmer-led research initiatives. In this context, the Ontario Government should provide opportunities for farmers and farmland owners to collaborate on the data collection for LUCI by keeping detailed records of their cropping and soil management practices, and crop yields. This collaboration would provide opportunities for farmers to demonstrate to government agencies and consumers their husbandry of agricultural soils, and evidence of their individual and collective on-farm efforts to improve the environmental performance and sustainability of their land. Ultimately, this approach will lead to reductions in GHG emissions from agriculture. Financial compensation, income derived from the market carbon, or property tax reduction to farmers who use beneficial management practices (i.e., conservation tillage, crop residue return, cover crops and green manures) should be considered by the provincial government. For example, to monitor progress in reducing emissions through a range of agricultural land management practices, the Australian Government has developed a voluntary Carbon Farming Initiative (CFI) whereby landholders may generate credits for reducing emissions and/or sequestering carbon. Currently it is not clear how Ontarian C offset credits generated by farmers would be managed; nevertheless, any $\mathrm{C}$ offset program would require a cost-effective LUCI and GHG estimation protocol to encourage farm owner participation and to facilitate $\mathrm{C}$ tracking and monitoring from agricultural soils. 


\section{Implementing the LUCI and Its Implication}

Cropland remaining cropland has been identified as a key category for Canada's GHG inventory, and the NIR acknowledges that the amount of carbon stored in, emitted by or removed from agricultural soils depends mainly on management practices. Since the intensively cultivated lands for agriculture in Ontario are a major component of Canada's total cropland area, changes in their management are expected to affect SOC stocks and impact Ontario's SOC budget. The CENTURY model can describe the main agricultural cropping systems and soil management practices (e.g., tillage intensity, crop rotations, cover crops) in Ontario for mineral soils. Should the province decide to implement a Tier 3 approach to estimate emissions and removals of $\mathrm{CO}_{2}$ within the LULUCF sector, the spatial framework to do so at a detailed sub-national scale is already in place. However, the accuracy of $\mathrm{CO}_{2}$ emissions and removals for the cropland category could be improved greatly using the current Tier 2 approach by incorporating more land-use-specific activity data that describe the influence of cropland management (e.g., erosion, manure) on SOC stocks beyond the segmentation of annual and perennial cropping systems. The Tier 1 approach for estimating SOC emissions from organic soils could also be improved by adopting a Tier 2 approach; both improvements would require substantial investment in empirical studies to determine appropriate estimates of $C$ stocks and $C$ emission factors for each of the unique soil-climate-management categories in which cropland is found.

\section{Conclusions and Recommendation}

This study reviewed current methods and approaches used to quantify $C$ stocks and GHG emissions for the cropland sectors in the context of emissions reporting from Canada and other countries. We have found that methods used to estimate emissions ranged from simple empirical factors to complex process-based ecosystem models. We have identified key gaps and proposed improvements to the methods used and the input data for models. For Ontario, we emphasize that a cropland specific method for carbon inventory GHG emission is needed to inform the development of mitigation strategies in the agricultural cropland sector. Such a method must balance accuracy with expense and ease of data collection. There is a requirement for a high number of detailed field sites, frequent on-site monitoring and soil $\mathrm{C}$ measurements to calibrate and validate the exiting CENTURY model.

Although there are some anomalies in the Canada's current soil carbon modeling approach, we have concluded that the CENTURY model is suitable for use under Ontario's conditions. There is, however, a need to refine the model, including the plant growth sub-model, to accommodate regional and management differences in agricultural soil $\mathrm{C}$ emissions and sequestrations to reduce model uncertainty. Should Ontario decide to implement its own LUCI, we recommend that a raster-based, spatially explicit, modeling approach be used instead of SLC-based polygon/census data. A raster-based spatiallyexplicit modeling approach would require the use of EO data (e.g., remote sensing maps, LiDAR). High-resolution topographic data for key cropland areas within the province is already (or becoming) available in the form of LiDAR-derived digital elevation models. This dataset, in combination with digital soil maps and EO data, could be incorporated into the model to include the influence of parameters such as erosion and manure management into inventory estimates of SOC emissions and removals from cropland. We recommend that harmonizing the LUCI to be compatible and consistent with the NIR should be a priority for the province. Fundamental to the approach is that it should be on a solid platform (i.e., a platform with High-performance computing web services), thus it is critical that a long-term program be initiated whereby detailed monitoring sites are identified and monitored, and possibly involving farmer cooperators. The data obtained from these sites would also provide valuable information that could be used for other purposes. Finally, an expected Ontarian carbon inventory should use high quality data and an improved modeling approach, thus, it should provide a better estimate than does NIR. The key is that the provincial inventory will need to be comparable and coherent with NIR, so that one can understand why there might be differences. Finally, it is important to emphasize 
that the final recommendations of this study could be used by some developing countries (i.e., African countries) as an inspiring document for the implementation and improvement of the compilation and reporting of their respective GHG inventories.

Author Contributions: A.L., P.R.V., A.W.G., A.C. have contributed substantially to the work reported here. This work was accomplished in both the University of Guelph and the UM6P-CRSA institutions. Conceptualization, A.L. \& P.R.V.; methodology, A.L., P.R.V. \& A.W.G.; validation, A.L., P.R.V., A.W.G. \& A.C.; formal analysis, A.L. \& P.R.V.; investigation, A.L. \& P.R.V.; writing-original draft preparation, A.L. \& P.R.V.; writing-review and editing, A.L., P.R.V., A.W.G. \& A.C.; supervision, A.L., P.R.V., \& A.W.G.; project administration, A.L., P.R.V.; \& A.W.G. funding acquisition, A.L. \& P.R.V.; writingreview and editing manuscript hosting Laboratory lead, A.C. All authors have read and agreed to the published version of the manuscript.

Funding: We acknowledge the financial support from Ontario Ministry of Agriculture, Food and Rural Affairs (OMAFRA) for the original project entitled: “Toward Ontario's Land Use Carbon Inventory of agricultural lands: What are the status, gaps, and needs? A Synthesis Report".

Data Availability Statement: Not Applicable.

Acknowledgments: We thank Kumudinie Kariyapperuma; Yuki Audette; Kimberly Zupfer; Lyne Blackburn, and Peter Nowell from the University of Guelph for their assistance in the review of the scientific literature and country-specific documentation of the original LUCI Synthesis Report. We also acknowledge Graham Epstein who was the OMAFRA coordinator/contact person of this project. We also acknowledge the LUCI Working Group and Science Group meeting for inviting the project PI, Laamrani, to their meeting in Sault Ste. Marie, Ontario in 2018. We greatly appreciate the meeting with Brian McConkey from Agriculture and Agri-Food Canada, section lead for the cropland sector of Canada's National Inventory Report (NIR). We also thank the academic editor and anonymous reviewers for their helpful comments which greatly improved earlier versions of the manuscript.

Conflicts of Interest: The authors declare no conflict of interest.

\section{References}

1. Ellis, E.C.; Klein Goldewijk, K.; Siebert, S.; Lightman, D.; Ramankutty, N. Anthropogenic transformation of the biomes, 1700 to 2000. Glob. Ecol. Biogeogr. 2010, 19, 589-606. [CrossRef]

2. Schlesinger, W.H.; Bernhardt, E.S. Biogeochemistry: An Analysis of Global Change, 3rd ed.; Academic/Elsevier: San Diego, CA, USA, 2013; pp. 1-688. [CrossRef]

3. Brady, N.C.; Weil, R.R. The Nature and Properties of Soils, 14th ed.; Prentice Hall: Hoboken, NJ, USA, 2008.

4. Friel, S.; Dangour, A.D.; Garnett, T.; Lock, K.; Chalabi, Z.; Roberts, I.; Butler, A.; Butler, C.D.; Waage, J.; McMichael, A.J. Public health benefits of strategies to reduce greenhouse-gas emissions: Food and agriculture. Lancet 2009, 374, 2016-2025. [CrossRef]

5. Sanderman, J.; Baldock, J. Accounting for soil carbon sequestration in national inventories: A soil scientist's perspective. Environ. Res. Lett. 2010, 5, 034003. [CrossRef]

6. Lal, R.; Delgado, J.; Gro_man, P.; Millar, N.; Dell, C.; Rotz, A. Management to mitigate and adapt to climate change. J. Soil Water Conserv. 2011, 66, 276-285. [CrossRef]

7. González-Sánchez, E.; Ordóñez-Fernández, R.; Carbonell-Bojollo, R.; Veroz-González, O.; Gil-Ribes, J. Meta-analysis on atmospheric carbon capture in Spain through the use of conservation agriculture. Soil Tillage Res. 2012, 122, 52-60. [CrossRef]

8. Kätterer, T.; Andersson, L.; Andrén, O.; Persson, J. Long-term impact of chronosequential land use change on soil carbon stocks on a Swedish farm. Nutr. Cycl. Agroecosyst. 2008, 81, 145-155. [CrossRef]

9. Söderström, B.; Hedlund, K.; Jackson, L.E.; Kätterer, T.; Lugato, E.; Thomsen, I.K.; Jørgensen, H.B. What are the effects of agricultural management on soil organic carbon (SOC) stocks? Environ. Evid. 2014, 3, 2. [CrossRef]

10. Sanden, T.; Spiegel, H.; Stuger, H.-P.; Schlatter, N.; Haslmayr, H.-P.; Zavattaro, L.; Grignani, C.; Bechini, L.; Dhose, T.; Molendijk, L.; et al. European long-term field experiments: Knowledge gained about alternative management practices. Soil Use Manag. 2018, 34, 167-176. [CrossRef]

11. Gonzalez-Sanchez, E.J.; Veroz-Gonzalez, O.; Conway, G.; Moreno-Garcia, M.; Kassam, A.; Mkomwa, S.; Carbonell-Bojollo, R. Meta-analysis on carbon sequestration through conservation agriculture in Africa. Soil Tillage Res. 2019, 190, 22-30. [CrossRef]

12. Gregorich, E.G.; Rochette, P.; VandenBygaart, A.J.; Angers, D.A. Greenhouse gas contributions of agricultural soils and potential mitigation practices in Eastern Canada. Soil Tillage Res. 2005, 83, 53-72. [CrossRef]

13. Bush, E.; Lemmen, D.S. Canada's Changing Climate Report; Government of Canada: Ottawa, ON, Canada, 2019; 444p, Available online: https:/ / www.nrcan.gc.ca/sites/www.nrcan.gc.ca/files/energy/Climate-change/pdf/CCCR_FULLREPORT-EN-FINAL. pdf (accessed on 1 June 2021). 
14. Statistics Canada. 2016 Census of Agriculture. Available online: https:/ / www.statcan.gc.ca/eng/ca2016 (accessed on 1 June 2021).

15. Climate Change 2014: Synthesis Report. Contribution of Working Groups I, II and III to the Fifth Assessment Report of the Intergovernmental Panel on Climate Change; Core Writing Team; Pachauri, R.K.; Meyer, L.A. (Eds.) IPCC: Geneva, Switzerland, 2014; 151p.

16. Guidelines for National Greenhouse Gas. Inventories, Volume 4: Agriculture, Forestry and Other Land Use; IPCC: Geneva, Switzerland, 2006. Available online: https:/ / www.ipcc-nggip.iges.or.jp/public/2006gl/ (accessed on 1 June 2021).

17. Houghton, J.T.; Meria Filho, L.G.; Lim, B.; Treanton, K.; Mamaty, I.; Bonduki, Y.; Griggs, D.J.; Callender, B.A. Climate Change 1995: The Science of Climate Change. Contribution of Working Group I to the Second Assessment Report of the Intergovernmental Panel on Climate Change; Cambridge University Press: Cambridge, UK, 1996.

18. Good Practice Guidance for LULUCF; Institute for Global Environmental Strategies: Hayama, Kanagawa, Japan. 2003. Available online: https:/ / www.ipcc-nggip.iges.or.jp/public/gpglulucf/gpglulucf_files/GPG_LULUCF_FULL.pdf (accessed on 1 June 2021).

19. Nemecek, T.J.; Schnetzer, J.; Reinhard, J. Updated and harmonised greenhouse gas emissions for crop inventories. Int. J. Life Cycle Assess. 2014, 21, 1361-1378. [CrossRef]

20. Eurostat 2018. Land Use and Land Cover Area Frame Survey (LUCAS). Available online: https://ec.europa.eu/eurostat/web/ lucas / data/primary-data/2018 (accessed on 1 June 2021).

21. Lugato, E.; Panagos, P.; Bampa, F.; Jones, A.; Montanarella, L. A new baseline of organic carbon stock in European agricultural soils using a modelling approach. Glob. Chang. Biol. 2014, 20, 313-326. [CrossRef]

22. Parton, W.J.; Scurlock, J.M.O.; Ojima, D.S.; Gilmanov, T.G.; Scholes, R.J.; Schimel, D.S.; Kirchner, T.; Menaut, J.-C.; Seastedt, T.; Garcia Moya, E.; et al. Observations and modeling of biomass and soil organic matter dynamics for the grasslands biome world-wide. Glob. Biochemic. Cycles 1993, 7, 785-809. [CrossRef]

23. Palmieri, A.; Martino, L.; Dominici, P.; Kasanko, M. Land cover and land use diversity indicators in LUCAS 2009 data. In Land Quality and Land Use Information; Tóth, G., Németh, T., Eds.; Publications Office of the European Union: Luxembourg, 2011; pp. 59-68.

24. Ministère de L'agriculture, de L'alimentation, de la Pêche, de la Ruralité et de L'aménagement du Territoire (MAAPRAT). Recensement agricole 2010 (RA2010). Available online: http:/ / www.agreste.agriculture.gouv.fr/ (accessed on 1 June 2021).

25. Rapport National d'Inventaire pour la France au titre de la Convention Cadre des Nations Unies sur les Changements Climatiques et du Protocole de Kyoto; FNIR: Paris, France. 2015. Available online: http:/ / temis.documentation.developpement-durable.gouv. fr/docs/Temis/0045/Temis-0045718/16176_2015.pdf (accessed on 1 June 2021).

26. UK Greenhouse Gas. Emissions National Statistics; Department for Business, Energy \& Industrial Strategy: London, UK, 2019. Available online: https://assets.publishing.service.gov.uk/government/uploads/system/uploads/attachment_data/file/87 5485/2019_UK_greenhouse_gas_emissions_provisional_figures_statistical_release.pdf (accessed on 1 June 2021).

27. Coleman, K.; Jenkinson, D.S. RothC-26.3-A model for the turnover of carbon in soil. In Evaluation of Soil Organic Matter Models Using Existing Long-Term Datasets; NATO ASI Series I; Powlson, D.S., Smith, P., Smith, J.U., Eds.; Springer: Berlin/Heidelberg, Germany, 1996; pp. 237-246.

28. Li, C.S.; Frolking, S.; Frolking, T.A. A model of nitrous-oxide evolution from soil driven by rainfall events. 1. Model structure and sensitivity. J. Geophys. Res. Atmos. 1992, 97, 9759-9776. [CrossRef]

29. Inventory of U.S. Greenhouse Gas. Emissions and Sinks: 1990-2016; US Environmental Protection Agency: Washington, DC, USA, 2018; EPA 430-P-18-001. Available online: https://www.epa.gov/sites/production/files/2018-01/documents/2018_complete_ report.pdf (accessed on 1 June 2021).

30. Parton, W.J.; Hartman, M.D.; Ojim, D.S.; Schimel, D.S. DAYCENT: Its land surface submodel: Description and testing. Glob. Planet. Chang. 1998, 19, 35-48. [CrossRef]

31. Del Grosso, S.J.; Ojima, D.S.; Parton, W.J.; Stehfest, E.; Heistemann, M.; DeAngelo, B.; Rose, S. Global scale DAYCENT model analysis of greenhouse gas emissions and mitigation strategies for cropped soils. Glob. Planet. Chang. 2009, 67, 44-50. [CrossRef]

32. Del Grosso, S.J.; Parton, W.J.; Adler, P.R.; Davis, S.C.; Keough, C.; Marx, E. DayCent model simulations for estimating soil carbon dynamics and greenhouse gas fluxes from agricultural production systems. In Managing Agricultural Greenhouse Gases: Coordinated Agricultural Research through GRACEnet to Address our Changing Climate; Academic Press: San Diego, CA, USA, 2012; pp. 241-250.

33. Potter, C.S.; Randerson, J.T.; Field, C.B.; Matson, P.A.; Vitousek, P.M.; Mooney, H.A.; Klooster, S.A. Terrestrial ecosystem production: A process model based on global satellite and surface data. Glob. Biogeochem. Cycles 1993, 7, 811-841. [CrossRef]

34. Potter, C.; Klooster, S.; Huete, A.; Genovese, V. Terrestrial carbon sinks for the United States predicted from MODIS satellite data and ecosystem modeling. Earth Interact. 2007, 11, 1-21. [CrossRef]

35. Lokupitiya, E.; Paustian, K. Agricultural soil greenhouse gas emissions: A review of national inventory methods. J. Environ. Qual. 2006, 35, 1413-1427. [CrossRef] [PubMed]

36. California Agricultural Statistics Review, 2018-2019 Report; CDFA-California Department of Food and Agriculture: Sacramento, CA, USA, 2019. Available online: https:/ / www.cdfa.ca.gov/statistics/PDFs/2018-2019AgReportnass.pdf (accessed on 1 June 2021).

37. Report on the State of Climate Action Plans in California; California Air Resources Board: Sacramento, CA, USA, 2019. Available online: https:/ / ww2.arb.ca.gov/sites/default/files/2020-03/17RD033.pdf (accessed on 1 June 2021).

38. Mascarenhas, M. Farming system research: Flexible diversification of a small family farm in southeast Michigan. Agric. Hum. Values 2001, 18, 391-401. [CrossRef] 
39. Inventory of U.S. Greenhouse Gas. Emissions and Sinks:1990-2014; U.S. Environmental Protection Agency: Washington, DC, USA, 2016; EPA 430-R-16-002. Available online: www.epa.gov/climatechange/ghgemissions/usinventoryreport.html (accessed on 1 June 2021).

40. National Inventory Report 2015; Government of Australia: Canberra, Australia, 2017. Available online: https://www.environment. gov.au/system/files / resources/97197b1e-07b9-4e6f-a08e-0f6145e681e5/files/national-inventory-report-2015-vol2.pdf (accessed on 1 June 2021).

41. Brack, C.L.; Richards, G.P. C accounting model for forests in Australia. Environ. Pollut. 2002, 116, 187-194. [CrossRef]

42. Richards, G.P. The Fullcam Carbon Accounting Model.: Development, Calibration and Implementation for the National Carbon Accounting System; Australian Greenhouse Office: Canberra, Australia, 2001; p. 50.

43. Viscarra Rossel, R.A.; Webster, R.; Bui, E.N.; Baldock, J.A. Baseline map of organic carbon in Australian soil to support national carbon accounting and monitoring under climate change. Glob. Chang. Biol. 2014, 20, 2953-2970. [CrossRef] [PubMed]

44. Australian Soil Resource Information System; Commonwealth Scientific and Industrial Research Organization; Department of Agriculture, Forestry and Fisheries: Canberra, Australia, 2013. Available online: http:/ / www.asris.csiro.au/index.html (accessed on 1 June 2021).

45. Agriculture Production Surveys and Censuses 2018; Stats New Zealand: Wellington, New Zealand, 2018. Available online: http:/ / datainfoplus.stats.govt.nz/Item/nz.govt.stats / 6362a469-f374-412e-ac25-d76fd0962003?_ga=2.200148782.1468439759.1 520379784-438291149.1520379784 (accessed on 1 June 2021).

46. New Zealand's Greenhouse Gas. Inventory: 1990-2015; New Zealand Government: Wellington, New Zealand, 2017; Available online: http:/ / www.mfe.govt.nz/sites/default/files/media/Climate_Change/FINAL_GHG_inventory-25_May.pdf (accessed on 1 June 2021).

47. Tate, K.R.; Wilde, R.H.; Giltrap, D.J.; Baisden, W.T.; Saggar, S.; Trustrum, N.A.; Barton, J.P. Soil organic carbon stocks and flows in New Zealand: System development, measurement and modelling. Can. J. Soil Sci. 2005, 85, 481-489. [CrossRef]

48. Trip Report-Japan Agricultural Situation; US Department of Agriculture (USDA): Washington, DC, USA. Available online: https: / /ipad.fas.usda.gov/highlights/2012/08/Japantrip/ (accessed on 1 June 2021).

49. Jiang, Q.; Qi, Z.; Xue, L.; Bukovsky, M.; Madramootoo, C.A.; Smith, W. Assessing climate change impacts on greenhouse gas emissions, $\mathrm{N}$ losses in drainage and crop production in a subsurface drained field. Sci. Total Environ. 2020, 705, 135969. [CrossRef] [PubMed]

50. National Inventory Report (NIR): Greenhouse Gas. Sources and Sinks in Canada; Environment Canada: Ottawa, ON, Canada, 2015. Available online: http:/ / www.publications.gc.ca/site/eng/9.506002/publication.html (accessed on 1 June 2021).

51. McConkey, B.; Canada's National Inventory Report (NIR) and Modeling Approaches. Personal communication, 2018.

52. Ministère du Développement durable, de l'Environnement et de la Lutte contre les changements climatiques.Inventaire Québécois des Émissions de Gaz à Effet de Serre en 2014 et Leur Évolution Depuis 1990. 2016. Available online: https: / / www.environnement. gouv.qc.ca/changements/ges/2014/Inventaire1990-2014.pdf (accessed on 1 June 2021).

53. Government of Canada. 2016 Census of Agriculture: Farm and Farm Operator Data. Available online: https://www150.statcan. gc.ca/n1/pub/95-640-x/95-640-x2016001-eng.htm (accessed on 1 June 2021).

54. Bolinder, M.A.; VandenBygaart, A.J.; Gregorich, E.G.; Angers, D.A.; Janzen, H.H. Modeling soil organic carbon stock change for estimating whole-farm greenhouse gas emissions. Can. J. Soil Sci. 2006, 86, 419-429. [CrossRef]

55. Hengl, T.; de Jesus, J.M.; Heuvelink, G.B.; Gonzalez, M.R.; Kilibarda, M.; Blagotić, A.; Shangguan, W.; Wright, M.N.; Geng, X.; Bauer-Marschallinger, B.; et al. SoilGrids250m: Global gridded soil information based on machine learning. PLoS ONE 2017, 12, e0169748. [CrossRef]

56. Congreves, K.; Hayes, A.; Verhallen, E.; Van Eerd, L. Long-term impact of tillage and crop rotation on soil health at four temperate agroecosystems. Soil Tillage Res. 2015, 152, 17-28. [CrossRef]

57. Laamrani, A.; Voroney, P.R.; Berg, A.A.; Gillespie, A.W.; March, M.; Deen, B.; Martin, R.C. Temporal Change of Soil Carbon on a Long-Term Experimental Site with Variable Crop Rotations and Tillage Systems. Agronomy 2020, 10, 840. [CrossRef] 